\title{
球形貯槽検査用ロボットの開発
}

$\begin{array}{rllllll}\text { 川口 圭 } & \text { 史* 曽 木 } & \text { 忠 幸* } & \text { 甲 斐 曻* } \\ \text { 森 } & \text { 崎 } & \text { 弘 康* } & \text { 早 川 秀 樹* }\end{array}$

\section{Development of an Inspection Robot for Spherical Storage Tanks}

\author{
Yoshifumi Kawaguchi*, Tadayuki Sogi*, Noboru Kai*, \\ Hiroyasu Morisaki* and Hideki Hayakawa*
}

\begin{abstract}
Recently new ultrasonic flaw detection system called TOFD method is utilized to externally inspect the inner and outer surfaces of weld seams on spherical storage tanks while tanks are in use. In this system, the robot mounted the sensors is not only permitted to travel along the weld seam rapidly but also required to follow the weld seam precisely. In this paper, the development of a magnetic-wheeled robot that can follow the weld seam within $5 \mathrm{~mm}$ based on feedback control is described. Since October 1999, this robot has been in experimental operation on an actual spherical tank. Practical introduction of this robot will shorten inspection time by about one week from the conventional 23 days, and will reduce the conventional number of inspectors required from 4 to 2-3.
\end{abstract}

Key Words: Mobile Robot, Inspection, TOFD Method, Magnetic Wheel, 2D Laser Displacement Sensor

1.は じめに

全国 552 基 [1]の球形ガスホルダー（以降 $\mathrm{GH}$ ) 等の球形貯槽 の検查は所有事業者にとって極めて重要な業務である。このた め日常検査以外に定期的 $(\mathrm{GH}: 10$ 年ごと）に溶接線付近の探 傷検查が行われている。この検査には開放検査「球形貯槽を開 放し, 内外面から磁粉探傷を行う検査』，および供用中検查『球 形貯槽を開放せず，外面からの超音波探傷を行う検査』の 2 種 類が認められている，検査性能としては開放検査が優れている が, 球形貯槽の用途 (GH：ガス供給量の調整) および検査コス 卜を考えると供用中検査の意義は大きい（ただし，GHでは少 なくとも 2 回に 1 回は開放検査が義務づけられている [2]).

近年 GH の供用中検査に用いる超音波探傷法としてパルス反 射法以外にTOFD 法 [3] が導入されている.この TOFD 法は溶 接線を挟んで一対の送受信センサを設置する方法（透過型）で あり，溶接線と平行にセンサを移動させる高速探傷が可能であ る.これにより従来のパルス反射法用の移動速度の遅い真空吸 着式ロボット [4]よりも, より高速移動が可能で効率化をもたら す検査ロボットが利用可能となった。

球形賍槽・壁面・管内などの高速移動用検査ロボットとして は磁石を用いた車輪型のロボット[5]～[8] がすでに提案されて いる. しかし TOFD センサを搭載したロボットはその検査目

原稿受付 2002 年 4 月 1 日

*大阪ガス株式会社

*OSAKA GAS CO., LTD.
的から溶接線に正確に追従した高速移動が必要である.しかし， これらのロボットでは，そのような検討は十分になされていな かった.

本稿では 2 回の試作 [9] [11] を経て, 開発した球形貯槽供用 中検査用ロボットの報告をする。このロボットは溶接線検知七 ンサと姿勢検知センサで左右車輪速度をフィードバック制御す ることにより，正確に溶接線追従し高速移動を実現している.

\section{T O F D 法}

TOFD（ Time Of Flight Diffraction）法は広い指向角（約 70 度）を持つ超音波を発生させ, 傷端部での回折波（360 度方 向）を検出する透過型の探傷検査である [3]. 複数センサの反射 波に基づき検査を行うパルス反射法と異なり，Fig. 1 の原理図 から分かるように，平行走査による高速探傷検査が可能である. 本ロボットに搭載している TOFD探傷装置は $15[\mathrm{MHz}]$ という 高周波の探触子を用いて高分解能を得ている.

この探傷装置はロボットの後部に搭載されており, 搭載に際 して以下の工夫がなされている。

・探触子の接触媒質は水を用い，地上ポンプからチューブを介 して供給する

・バネによる探触子押し付け力が溶接線乗越え時に支障となる ため，地上から操作可能な探触子昇降装置を設置する

・ロボットの移動速度の拘束を緩めるために，ロボット搭載エ ンコーダの值を探傷装置に取り込み（横軸として）探傷画面 を表示する (Fig. 1参照) 
Artificial slits

(1) : Longitudinal crack

(2) : Transverse crack

(3) : Longitudinal crack
$\mathrm{L}=25 \mathrm{~mm} \quad \mathrm{~d}=4.4 \mathrm{~mm}$

$\mathrm{L}=0.5 \mathrm{~mm} \quad \mathrm{~d}=4.0 \mathrm{~mm}$

$\mathrm{L}=25 \mathrm{~mm} \mathrm{~d}=3.4 \mathrm{~mm}$
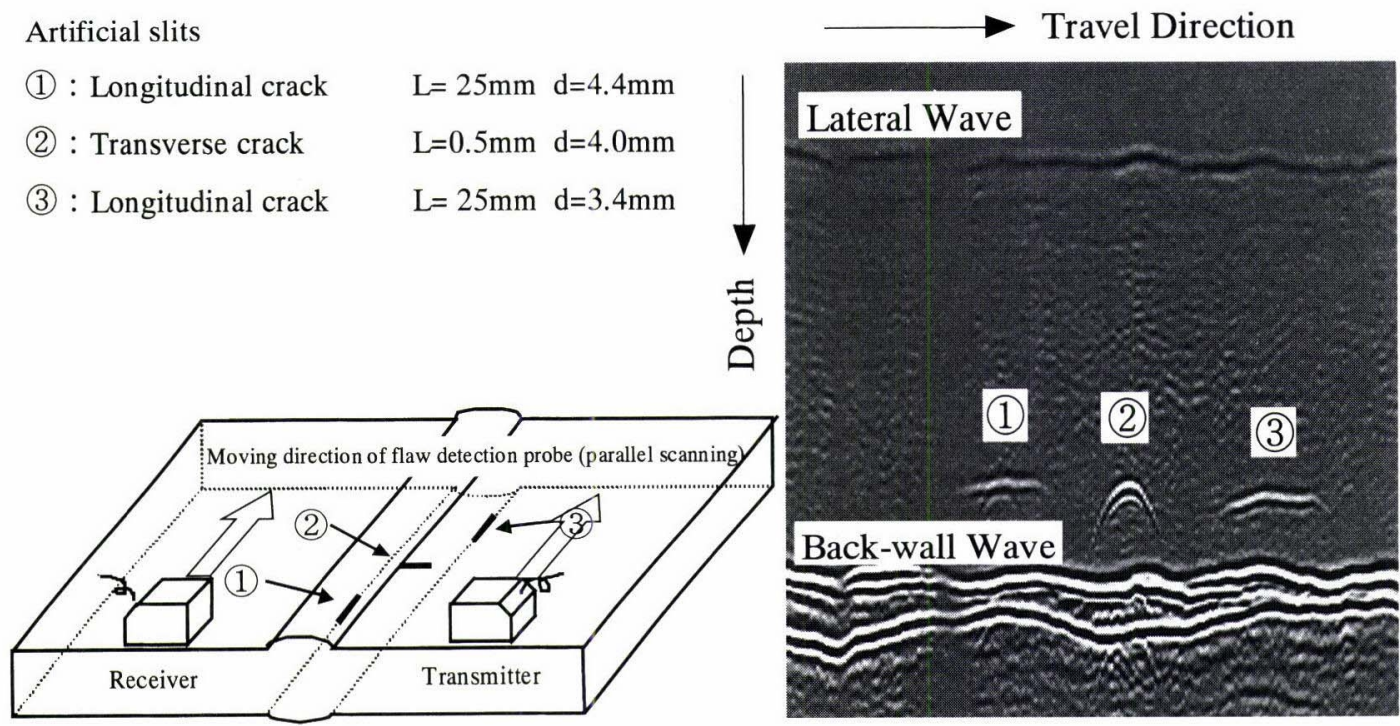

Fig. 1 Location of defect on specimen and corresponding image

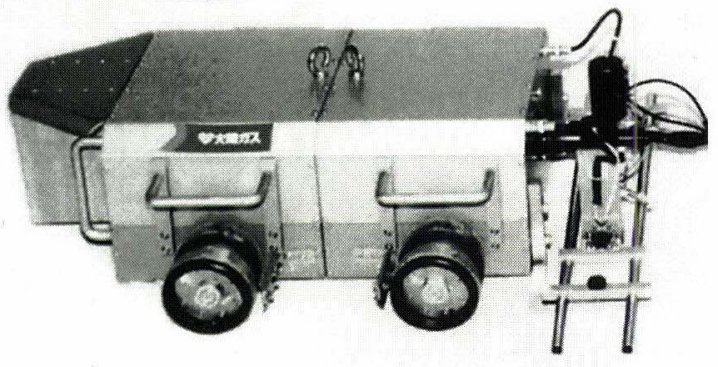

\begin{tabular}{|l|l|}
\hline Size & Length 536mm Width 428mm Height $177 \mathrm{~mm}$ \\
\hline Weight & $27.5 \mathrm{~kg}$ \\
\hline Speed & $0-3 \mathrm{~m} / \mathrm{min}$ \\
\hline Power Source & DC 30 V supplied from outside source \\
\hline Sensors & $\begin{array}{l}\text { 2-Dimensional Laser Displacement Sensor } \\
\text { Ultrasonic Flaw Detection Probe (TOFD method) } \\
\text { 3-Axis Tiltmeter } \\
\text { Odometers } \\
\text { Hall Sensors } \\
\text { Color CCD Camera }\end{array}$ \\
\hline
\end{tabular}

Fig. 2 Picture and specification of the robot

3. 球形貯槽検査用ロボット

Fig. 2 に開発した球形貯槽走行ロボットの写真および仕様を 示す. 本ロボットは球形貯槽への付着のためにネオジム鉄系の 永久磁石（付着力 $539[\mathrm{~N} /$ 輪 $]$ ）をそれぞれ一つ用いた四輪独立 駆動 [5] [8] を採用している（前後の独立性は主に動作確認用）. さらに磁石車輪の付着状態を改善するため, 車輪を球形貯槽に 合わせた曲率とするだけでなく，前後車輪間にねじれ機構を採 用している。ただしロボットが上下方向に移動姿勢をとってい る場合には車輪の空転が発生する。この転がりを防止するため, 停止時掞よび電源遮断時に車輪をロックできる機構を採用して いる．走行速度は最大 $3[\mathrm{~m} /$ 分] であるが，検査時はTOFD 探 傷装置の処理能力から $1 \sim 2[\mathrm{~m} /$ 分 $]$ としている.

TOFD 探傷装置には検査用に水供給チューブが必要であり, エネルギー的な自立の優位性は低いため，本ロボットでは地上 からケーブルでエネルギーを供給している。

本ロボットには, 後述する溶接線検知センサ（レーザ変位セ ンサ), 姿勢検知センサのほかにエンコーダ（四輪すべて），溶

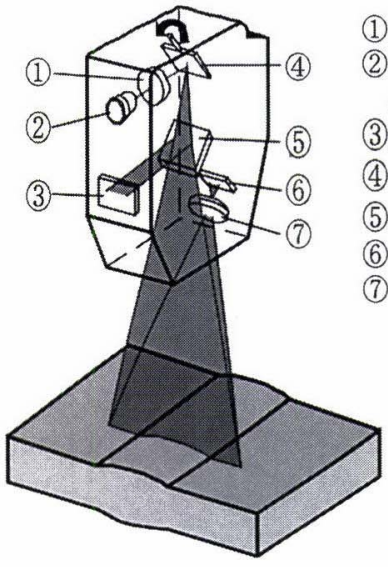

(1)Projection lens (2) Semiconductor laser element (3) X-directional PSD

(4) Scanner

(5) Half mirror

(6) Z-directional PSD

(7) Converging lens

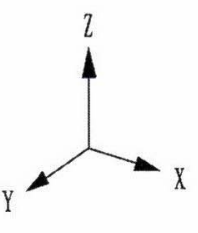

Fig. 3 Construction of 2D laser displacement sensor

接線確認用 CCD カメラ (スリットレーザ付)，ロボット内部の 温度センサ (2 筒所), 付着状態確認用ホールセンサ（四輪すべ て) [12]が搭載されている.特にホールセンサは以下のような多 

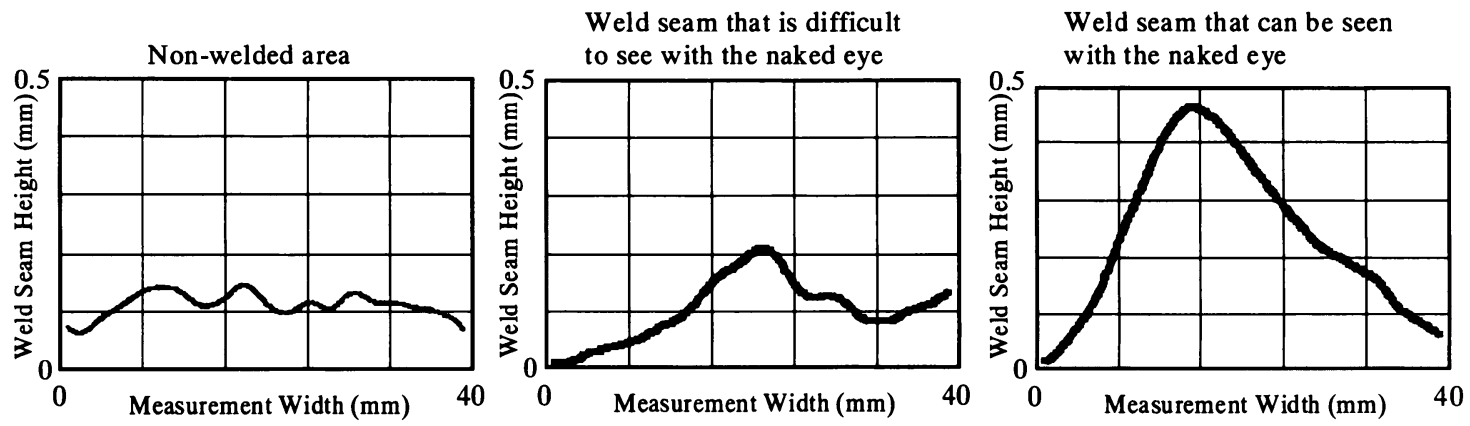

Fig. 4 Example of weld seam contour measurement

様な用途がある.

- 溶接線乗越え時の状況（安定性）確認

- 車輪の磁石が割れた際の検知

・ロボットが球形貯槽から剥離している状態（レーザが眼に当 たる危険性のある状態）の検知（眼球防護）

さらに本ロボットの目的はTOFD探傷検査の効率化（検査の 継続・簡単な操作）でありこの観点から設計・開発に際して は以下の点に特に留意した

-入手しやすい汎用交換部品採用

・複合ケーブル（通信・エネルギー・水）の採用

・消耗品（モータ・ギア・車輪）取替が簡便な構造

・運搬の容易なアイディア（ロボットの複数取っ手・専用箱）

・優れた操作性 (CCD カメラ画像も制御用 PC で表示)

\section{4. 溶接線検知センサ}

球形貯槽検査用ロボットの溶接線検知として, 渦電流を用い る方法がすでに提案されている [13]. しかし, 装置が大型になっ たり，母材の影響による誤差があるため，本ロボットではFig. 3 に示すレーザ変位センサ [14]（検知横幅 40 [mm], サンプリン グ周期 $30[\mathrm{~ms}]$, 取込データ 50 点, 高さ精度 $10[\mu \mathrm{m}])$ をロ ボット頭部に搭載している。これにより溶接線断面形状を計測 L (Fig. 4 参照)， $0.3[\mathrm{~mm}]$ 以上の高さを持つ溶接線の中心位 置が計算できる（実験結果：位置誤差の標準偏差 $2.3[\mathrm{~mm}]$ ). 中 心位置の判定は以下の規準で行う。

・レーザの高さ最大值が $0.3[\mathrm{~mm}]$ 未満の場合は判定不能とする (フィードバック制御にはゼロを返す)

・高さ最大値が $0.3 \sim 1.0[\mathrm{~mm}]$ の場合は, 高さ最大值の位置を 中心位置とする

•高さ最大值が $1.0[\mathrm{~mm}]$ 以上かつ最大值よりも $0.5[\mathrm{~mm}]$ 小さ い値の 2 点の幅（3点以上の場合は最大）が $10[\mathrm{~mm}]$ 未満の 場合は, 高さ最大値の位置を中心位置とする

• 高さ最大值が $1.0[\mathrm{~mm}]$ 以上かつ最大值よりも $0.5[\mathrm{~mm}]$ 小さ い值の 2 点の幅（3 点以上の場合は最大）が $10[\mathrm{~mm}]$ 以上の 場合は，その幅の中央を中心位置とする

この計算はロボット搭載の CPUで行い, ピーク位置のみを 地上 PCへ通信している. また Fig. 5 に示す走行試験データよ り，ロボット走行に伴う振動の影響を受け難いことを確認した.

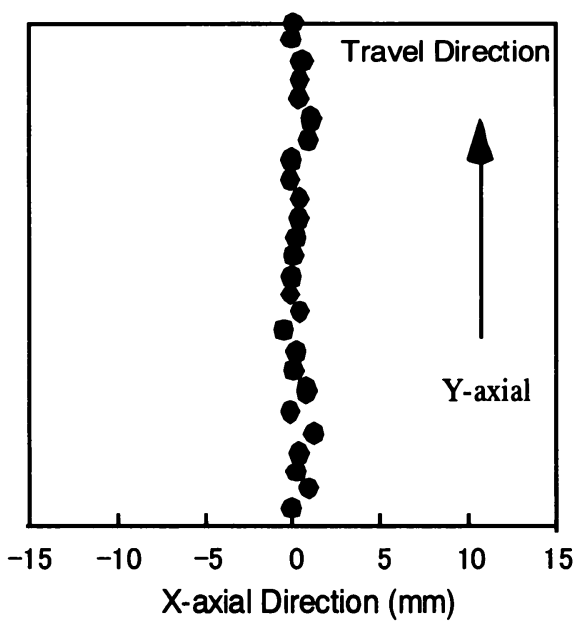

Fig. 5 Variation of weld seam center

\section{5. 姿勢検知センサ}

本ロボットの姿勢検知には 3 軸の静電容量式傾斜センサを用 いている， 3 軸傾斜センサの各出力 $x, y, z(x$ 軸をロボットの 車輪軸と平行な軸 (上から見て左 $\rightarrow$ 右),$y$ 軸をロボットの前進 方向と一致する軸とする）は，その軸が重力べクトルとなす角 度を $\psi_{i}(i=x, y, z)$ としたときに

$$
i=a_{i} \cos \psi_{\imath}+b_{i} \quad(i=x, y, z)
$$

となる。ただし $a_{i}, b_{i}$ はそれぞれ既知の定数である.

また球形貯槽付着の拘束条件から, Fig. 6 で定義した緯度 $\phi$ （北緯を正值で表現）およびロボットと溶接線（溶接線は等緯度 または等経度線しかない) との角度である振り角 $\theta$ に関して次 式が成立する。

$$
\begin{gathered}
\phi=\sin ^{-1} z \\
\theta=\sin ^{-1} \quad(x / \cos \phi)
\end{gathered}
$$

および

$$
\theta=\cos ^{-1} \quad(-y / \cos \phi)
$$

ここで, 緯度はその定義から $-\pi / 2<\phi<\pi / 2$ であり, 式 （2）は一意解を持つ。また式 $(3)$, （4）より振り角も一意に決 


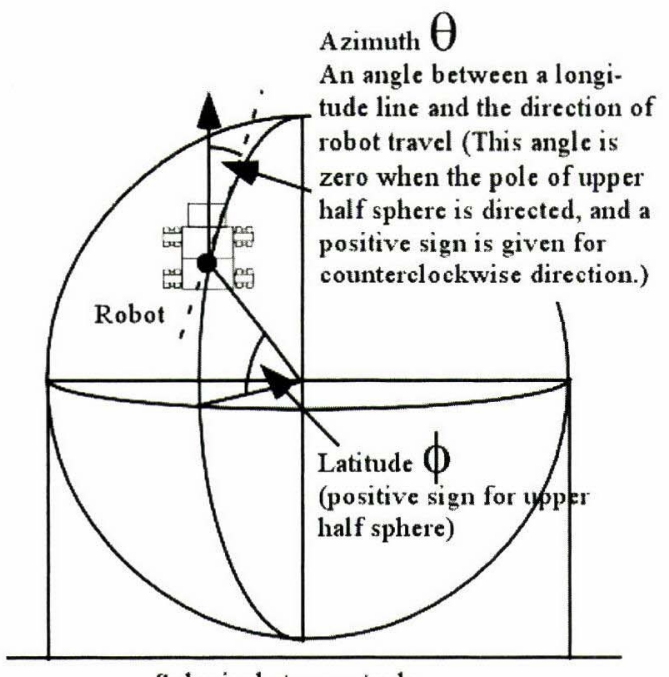

Spherical storage tank

Fig. 6 Definition of latitude and azimuth for the robot

[mm]

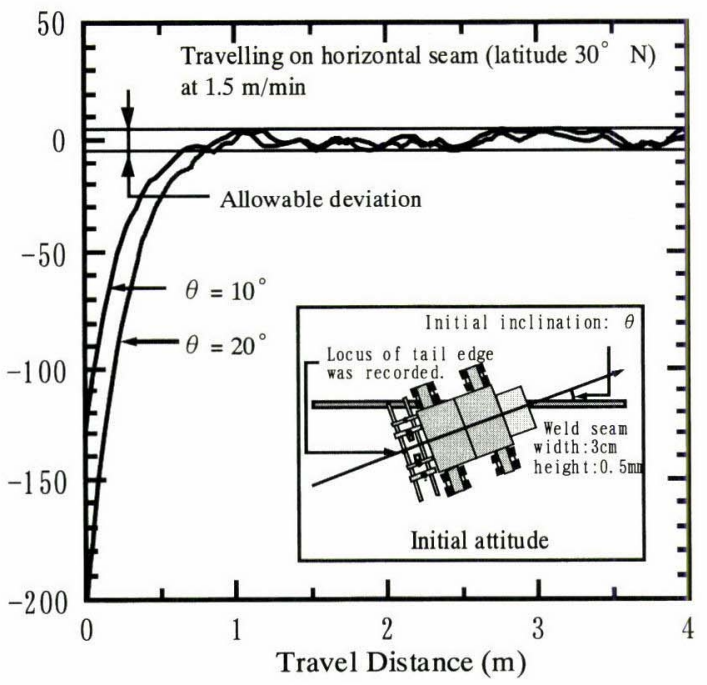

Fig. 7 Results of automatic weld seam following test on specimen

定できる. 式 (3), (4) の使い分けとしては $\theta$ の絶対值が小さ い縦方向の移動は式 (3), 横方向は式 (4) というように誤差の 影響の少ない方を選んでいる。

\section{6. 溶接線追従制御}

本ロボットはTOFD 探傷装置を走査させるという目的から， 溶接線ピーク位置から士5 $[\mathrm{mm}]$ 以内のずれで追従しなければ ならない。 そこで走査速度（左右輪の平均速度）一定となるよ うに前述の溶接線検知センサと姿勢検知センサによるフィード バック制御を左右車輪に施す.

溶接線検知センサの值を $L[\mathrm{~mm}]$, 姿勢検知センサより得られ る振り角 $\theta[\mathrm{rad}]$, 目標振り角（定数）を $\theta^{\prime}[\mathrm{rad}]$, ロボットの左 右輪の速度を $v_{L}, v_{R}[\mathrm{~mm} / \mathrm{s}]$ とするとロボットの挙動は以下の ようになる。

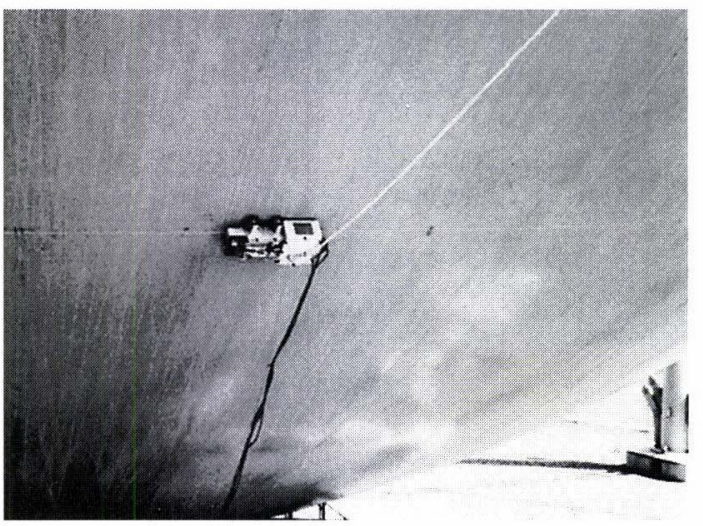

Fig. 8 Field testing

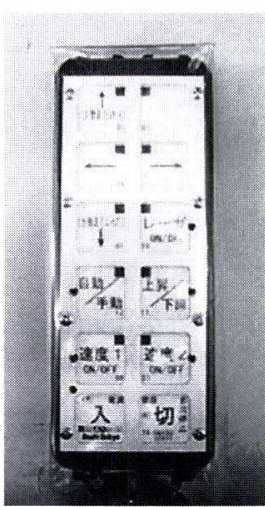

Fig. 9 Controller

$$
\begin{gathered}
d L / d t=-v \sin \left(\theta-\theta^{\prime}\right) \\
d \theta / d t=\omega \\
v=\left(v_{L}+v_{R}\right) / 2 \\
\omega=\left(v_{R}-v_{L}\right) / w
\end{gathered}
$$

ただし $w[\mathrm{~mm}]$ は車輪間隔

式（5）は $\left(\theta-\theta^{\prime}\right) \ll 1$ と近似すると

$$
d L / d t=-v\left(\theta-\theta^{\prime}\right)
$$

と書き直せるので, 式 $\left.(5)^{\prime}, （ 6\right)$ は $L$ に関する 2 階の線形微分 方程式となる。 $\omega$ をと $\left(\theta-\theta^{\prime}\right)$ の線形結合值としてフィード バックすれば $L,\left(\theta-\theta^{\prime}\right)$ を安定化できることになる $(v$ が一定

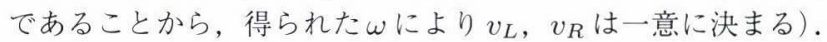

Fig. 7 に余盛りの小さい現場溶接線を模擬したテストピース 上での制御結果を示す。ロボットの初期姿勢が溶接線に対し約 20 度傾いていても, 距離 $1[\mathrm{~m}]$ 以内で許容範囲内にずれ量を修 正でき，その後も許容範囲を超えることはなかった。

ここで用いた方法は通常の状態フィードバックであり, 初期 状態が不適切である場合や外乱の影響によっては目標值を保証 することはできない。このため本方法の妥当性（実用性）は実 際の球形貯槽での走行試験結果で評価する必要がある。

\section{7. 現 場 適 用}

1999 年 8 月に実際の $\mathrm{GH}$ （直径約 $30[\mathrm{~m}]$ ）において, 剥離の 


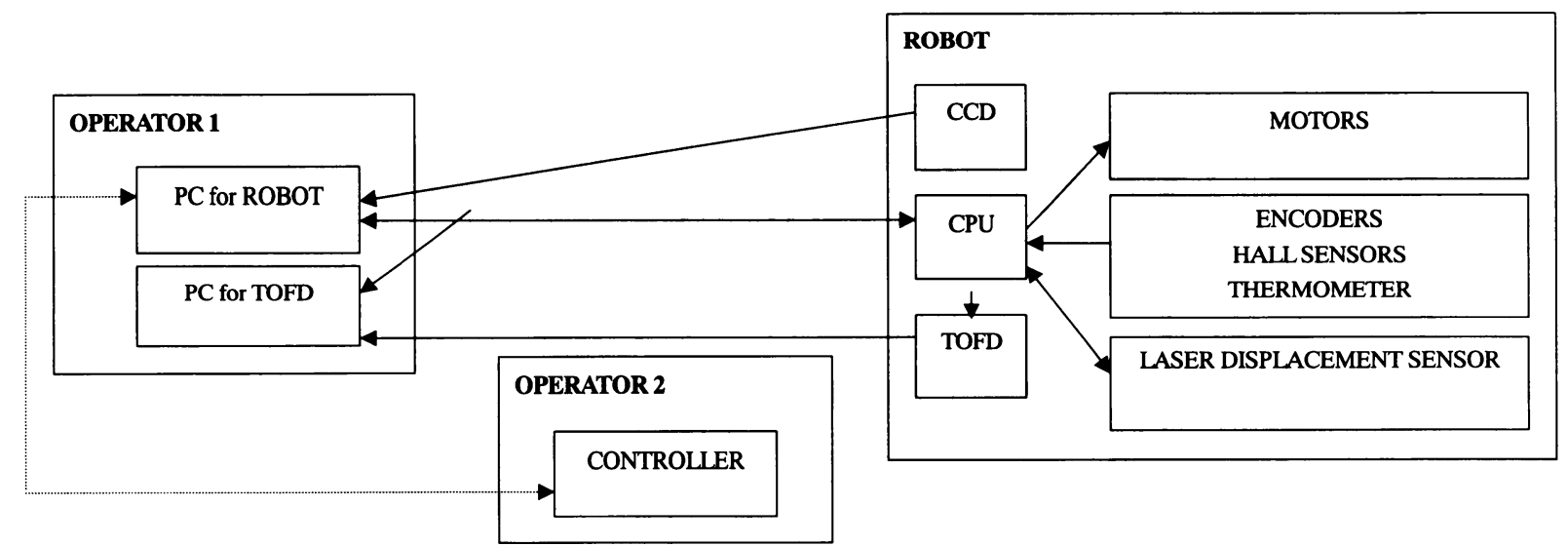

Fig. 10 System configuration

危険性の高い下半球で走行試験を行った (Fig. 8参照)，その結 果, 溶接線縦走行 (上向き), 横走行 (右向き, 左向き) の両方 で良好な溶接線追従性能を確認できた。また初期状態の設定に 関しても，『操作者によるおおまかな位置設定（溶接線ピーク位 置が測定レンジ範囲内）後に初期設定のために（事前）自動走 行を施す』ことが効果的であると分かった．また懸念されてい た外乱の影響はほとんどなかった。

この結果を受けて本ロボットを 2000 年 10 月から大阪ガス（株） 伏見供給所の GH の供用中検査に適用した（すでに TOFD 法は 採用済)。その結果 1 日に最大 $120[\mathrm{~m}]$ の検査が実現し（従来約 $50[\mathrm{~m}])$ ，大幅な検査効率の向上が実現した。

ただ縦溶接線の検査（地上装置固定で左右 3 本ずつの検査 が可能）を行う際に，操作者の視野からロボットが外れる状況 が発生した，そこでロボットの基本操作（前進後退, 旋回, レー ザON/OFF, 自動手動切替, 自動スタートノストップ）が可能 な無線操作機を開発した (Fig.9参照)。その結果, 最終的に構 成されたシステムの情報の流れを Fig. 10 に示す.

\section{8. フィードフォワード制御追加による横方向検查性能改善}

本ロボットが横方向の溶接線検查を行う場合に，その軌跡は 赤道（中央）以外は球の最大円を描くことができない。このた め左右輪を同速度で移動すると，(外乱の影響ではなく）最大円 を描く方向にずれていく。これは横方向の検査では常にフィー ドバック制御が機能していることを示す。しかしこれは緯度 $\phi$ により決まる（事前に分かる）ため，フィードフォワード制御 を追加し, フィードバックの負荷を隇らすことが望ましい.

ロボットの車輪幅に相当する緯度差 $2 \delta$ (これは球径 $r に$ 依存) とすると赤道側車輪および極側車輪の全周移動距離はそれぞれ

$$
\begin{aligned}
& 2 \pi r \cos (\phi-\delta) \\
& 2 \pi r \cos (\phi+\delta)
\end{aligned}
$$

となるため，赤道側の車輪のスピードを

$$
\cos (\phi-\delta) / \cos (\phi+\delta)
$$

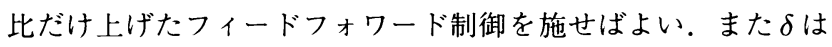

十分小さいので式（11）を

$$
(\cos \phi+\delta \sin \phi) /(\cos \phi-\delta \sin \phi)
$$

と近似しても構わない.

さらに車輪と球形貯槽との接地状態の微妙な変化により重力 方向へ横滑りを起こす場合がまれにある。このため横方向の検 査にはTOFD探触子の位置を検査に支障のない範囲で球頂側に 設定している.

\section{9. ま と め}

本稿ではTOFD 法センサを搭載させた, 溶接線付近の高速探 傷検査が可能な球形貯槽検査用ロボットの開発について述べた。

すでに本ロボットは実際の球形ガスホルダーで供用中検査に 適用し，良好な結果を得ている。これにより GHの供用中検査 においては平均検査期間 23 日が 18 日に，検査・操作員が 4 人 から $2 \sim 3$ 人に削隇される見通しである．今後は現場実績を重ね てさらに信頼性を向上させていく.

\section{参考文 献}

[1] 社団法人日本ガス協会: ガス事業便筧 (平成 13 年度版).p.172, 社 団法人日本ガス協会, 2001 .

[2] 社団法人日本ガス協会: 球形ガスホルダー指針. p.247, 社団法人日 本ガス協会, 1989 .

[3] 西田, 藤本: “TOFD法を利用した超音波探甥技術”, 溶接技術, no.10, pp.72-79, 1995.

[4] 柘植: “球形ガスホルダーの検査ロボット”, 日本ロボット学会誌, vol.10, no.5, pp.599-601, 1992.

[5] 中村: “球形ガスホルダー脚栓隅肉溶接部自動検査ロボット”, 七ンサ 技術, vol.10, no.2, pp.77-80, 1990 .

[6] 佐藤：“実用ロボット技術に必要なもの一壁面ロボット，管内ロボッ トを例に一”, 日本ロボット学会誌, vol.12, no.8, pp.1132-1136, 1994.

[ 7 ] 萩尾, 田中, 藤沢, 佐藤：“車輪型壁面走行ロボットの開発”, 日本銅 管技報, no.122, pp.176-181, 1988.

[ 8 ] 川口, 吉田, 車谷, 菊田: “鉄管内走行ロボットの開発”, 日本ロボッ 卜学会誌, vol.14, no.1, pp.137-143, 1996.

[9] 曽木, 川口, 早川, 森崎, 甲斐, 大河: “球形ホルダー走行ロボット の開発”, 第 17 回日本ロボット学会学術講演会予稿集, pp.345-346, 1999.

[10] 曽木, 川口, 甲斐, 大河: “球形貯槽検査用ロボットの開発”, SI-2000, pp.223-224, 2000. 
[11] J. Sogi, Y. Kawaguchi, H. Morisaki, K. Ohkawa, N. Kai and H. Hayakawa: "Inspection Robot for Spherical Storage Tanks," IECON-2000, pp.393-398, 2000.

[12] 川口, 吉田, 嚴, 菊田：“鉄管内走行ロボットのセンサと円周方向走 行”, 日本ロボット学会誌, vol.15, no.8, pp.1164-1171, 1997.
[13] 中村：“無軌道式超音波探傷装置”, 日本ロボット学会誌, vol.10, no.5, pp.601-603, 1992

[14] キーエンス株式会社：二次元レーザ変位センサインストラクションマ ニュアル.

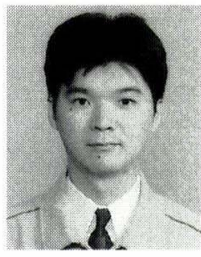

川口圭史（Yoshifumi Kawaguchi）

1964 年 4 月 7 日生. 1989 年神戸大学大学院修上課 程修了。同年より大阪ガス株式会社に勤務. 1992 1993 年オハイオ州立大学客員研究員. 現在導管維 持管理技術の開発に従事. 工学博士。

(日本ロボット学会正会員)

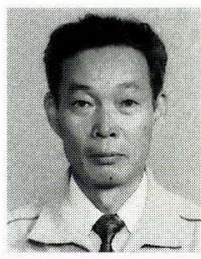

\section{甲斐 曻（Noboru Kai）}

1949 年 6 月 19 日生. 1967 年大阪ガス高等学園卒 業. 同年より大阪ガス株式会社に勤務. 現在生産設 備維持管理技術の開発に従事.

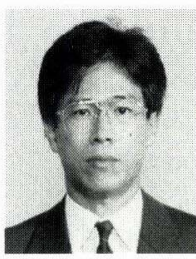

\section{早川秀樹（Hideki Hayakawa）}

1962 年 4 月 8 日生. 1987 年大阪大学大学院修士課 程修了. 同年, 大阪ガス (株) 総合研究所に入所. 1990 1994 年 ATR 視聴覚機構研究所，ATR 人間 情報通信研究所に出向. 現在, 大阪ガス (株) 開発 研究部シニアリサーチャ一. 計測・診断技術の開発 に従事. 工学博士，電子情報通信学会，日本非破壊 検査協会，物理探査学会各会員.

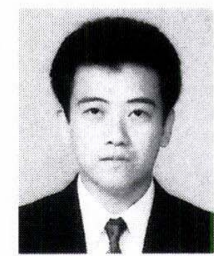

曽木忠幸（Tadayuki Sogi）

1965 年 7 月 30 日生. 1989 年東京大学工学部卒業. 同年より大阪ガス株式会社に勤務．現在導管維持管 理技術の開発に従事.

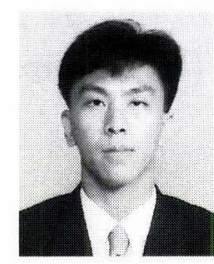

森崎弘康（Hiroyasu Morisaki）

1969 年 9 月 11 日生. 1995 年大阪大学大学院修士 課程修了. 同年より大阪ガス株式会社に勤務. 現在 導管の溶接・検査技術の開発に従事. 